\title{
Filippino Lippi and Music
}

\author{
TIMOTHY J. MCGEE \\ Trent University
}

Un examen attentif des illustrations musicales dans deux tableaux de Filippino Lippi nous fait mieux comprendre les intentions du peintre. Dans le «Portrait d'un musicien », l'instrument tenu entre les mains du personnage, tout comme ceux représentés dans l'arrière-plan, renseigne au sujet du type de musique à être interprétée, et contribue ainsi à expliquer la présence de la citation de Pétrarque dans le tableau. Dans la « Madone et l'enfant avec les anges $\gg$, la découverte d'une citation musicale sur le rouleau tenu par les anges musiciens suggère le propos du tableau.

$I^{n}$

$\mathrm{n}$ addition to their value as art, paintings can also be an excellent source of information about people, events, and customs of the past. They can supply clear details about matters that are known only vaguely from written accounts, or in some cases, otherwise not known at all. For the field of music history, paintings can be informative about a number of social practices surrounding the performance of music, such as where performances took place, who attended, who performed, and what were the usual combinations of voices and instruments - the kind of detail that is important for an understanding of the place of music in a society, but that is rarely mentioned in the written accounts. Paintings are a valuable source of information concerning details such as shape, exact number of strings, performing posture, and the like, especially when the painter was knowledgeable about instruments and performance practices, or took the time to represent these elements with precision. ${ }^{1}$ Not all paintings were intended to be realistic portrayals of contemporary scenes, however, and the viewer, especially those of us who are not art specialists, must be careful to understand context and intention in order to separate realistic scenes from fantasy or symbolism. ${ }^{2}$

It is also true that in some cases an understanding of the symbolism of the musical images can supply additional information about the painting. ${ }^{3}$ Exchange of information between specialists in the fields of music and art, therefore, has the potential of being beneficial to both areas of study, as this essay will attempt to show through an investigation of the musical images in two paintings by Filippino Lippi. 
Filippino belongs to that stream of later Quattrocento Florentine painting in which topographical accuracy and careful attention to detail was particularly valued. ${ }^{4} \mathrm{He}$ included musical images, mostly instruments, in a number of his works: some are clearly realistic representations of contemporary instruments, others are obviously intended to be symbolic; occasionally the two types are found in a single work. "The Adoration of the Golden Calf" in the National Gallery of London is a good example of a mixture of real and imaginary instruments. The painting includes realistic and accurate images of nakers (a pair of small drums), a tambourine, and a trumpet in an "S" shape, all of which would have been in use during his time. ${ }^{6} \mathrm{In}$ the same panel, however, he includes a circular shaped tuba, or buccina, from early Roman times, another trumpet with two bells but one mouth pipe, something that would be impossible to play, and a mythological lyre that is depicted in a form that would make it also impossible to play.7 His "Allegory of Music," now in the Berlin Staatsmuseum, includes a fanciful lyre constructed on the head of a stag, as well as more realistic images of a panpipe and a tiny wind instrument that could be a shawm or recorder. And in his "Assumption of the Virgin" in the Carafa Chapel in Santa Maria sopra Minerva, he again presents the viewer with a mixture of realistic and fantastic instruments. This painting has been especially helpful to music historians because it includes the earliest known accurate depiction of a trombone, an instrument whose date of origin has been much debated. ${ }^{8}$

There is no doubt that on some occasions Lippi was indulging in flights of fantasy, as can be seen as well in the detailed but completely unplayable instruments he places in the hands of angels in the Brancacci chapel; images described by Emanuel Winternitz as "a veritable goldmine of Renaissance misinterpretations of antiquity." 9 Two of his paintings, however, "Portrait of a Musician" in the National Gallery of Ireland, and the tondo "Madonna and Child with Angels" now at Ente Cassa di Risparmio di Firenze, (illustrations 1 and 3 ) include realistic portrayals of music that have been extremely helpful to the field of music history; and in return, the musical images also may provide additional information for an understanding of the paintings, their contents, and their purpose.

\section{Portrait of a Musician}

In his "Portrait of a Musician," (Illustration 1) Filippino includes musical instruments as a way of identifying his subject as a musician. ${ }^{10}$ On the shelf above the head of the musician we can see a lute placed upside down, the mouthpiece of one recorder and the bottom end of another, and a lira da braccio with its bow; another 
lira da braccio is in the hands of the musician. On the shelves with the instruments there is an open book and a separate sheet of paper, neither with legible writing or anything that would indicate their contents. ${ }^{11}$ Because of their placement with the instruments, however, it is possible that they were intended to represent written music in the two different formats common at that time-loose sheets and bound copies - both in manuscript, in this painting from the 1480 s, since the printing of music did not begin until $1500 .{ }^{12}$ Taken as a group, the musical instruments represent a variety of types of domestic music making, including singing and playing that involved plucked instruments (lute), bowed instruments (lire da braccio), and woodwinds (recorders). Missing from the painting is any representative of outdoor instruments: trumpets, bagpipes or pifferi had a completely different cultural association and were never a part of domestic performance. ${ }^{13}$ Further, the lira da braccio represents improvised performance, the cantare all' improvviso tradition in which a poet sings his verses while accompanying himself, improvising both the melody and the instrumental accompaniment. Since the musician is tuning one of the strings of his lira da braccio, the emphasis in the painting is clearly on improvised music and its tradition, which helps us understand the presence across the back of the instrument of a line of text from one of Petrarch's canzione, a type of text that would have been performed in this manner.

In the late fifteenth century the lira da braccio, a descendent of the earlier 5 -string fiddle (also commonly referred to in Italy as a viola), was the favoured instrument of the Italian poet-improvisors along with the lute and the harp, all of which had been associated with that style of performance dating back at least as early as the thirteenth century. ${ }^{14}$ The fiddle/lira was intimately associated with the tradition of improvised performance of poetry, and in fact, whereas the lute and other instruments were involved in a great variety of music, until well into the sixteenth century the fiddle/lira was associated exclusively with the cantare all'improvviso repertory. ${ }^{15}$ (It was not until the last decades of the fifteenth century that the instrument began to be referred to as a lira da braccio rather than viola.) By the early sixteenth century the shape took on some of the curved body details of the newly developed violin family, ${ }^{16}$ and the number of strings was expanded from five to seven. The name lira was intended to link the instrument symbolically to the lyre of ancient times as well as to the poet-musicians of classical mythology, undoubtedly an association reinforced, if not wholly initiated, by the burgeoning humanistic movement, although the instrument itself is from much earlier. Images of a bowed instrument that can be identified as a prototype lira da braccio are found in stained glass, manuscript illuminations, and sculptures from as early as the twelfth century. 
Most are from Italy, but there are also examples from Saxony, Austria, France, and England, suggesting that although it was most popular in Italy, the instrument was pan-European during the late Middle Ages. ${ }^{17}$ During the Renaissance the lira da braccio represented not only the kithera from ancient Greece, but also Orpheus' classical lyre, the lyre of Apollo, and the lyre (or sometimes harp) of King David; it was often used as the symbol of poetry. ${ }^{18}$ Although in shape of the ancient kithera and lyre-both harp-like instruments - would have been more accurately represented by a medieval or Renaissance harp than by a lira da braccio, the ancient instruments and the fiddle/lira da braccio were directly related on the level of function: that is, their association with accompanied, serious poetry.

The popularity of the fiddle/lira grew in Italy through the late Middle Ages and Renaissance into the seventeenth century, when it finally disappeared. During that time, it existed in several different sizes and a variety of body shapes and with both five and seven strings. ${ }^{19}$ In the sixteenth century the most frequently depicted instrument had seven; a number that may well have been chosen to align the instrument symbolically with the seven strings on the ancient kithera or lyre. ${ }^{20}$ The fiddle/lira is unique in that it combines both plucked and bowed strings: on the seven-string instrument, five of the strings crossed the fingerboard and could be stopped by the fingers of the left hand, changing their pitches. These were to be sounded by the bow which is held in the right hand. Two additional strings were off-board, that is, they did not pass across the fingerboard and therefore their pitches could not be changed. They served as drones and were plucked by the thumb of the left hand. ${ }^{21}$ Lippi's portrait is the earliest depiction of the instrument to provide such clear details of the construction of the peg box and the attachment of the offboard string. ${ }^{22}$ As can be seen, this instrument has only five strings (as do most of the earlier depictions): four pass over the fingerboard, and the fifth, the string the musician is tuning, is the off-board, plucked string. The performer, therefore, could play sustained notes with the bow and at the same time provide his own rhythm by plucking the other string(s), while he sang poetry, improvising both his melody and its accompaniment. It is significant that in a large number of depictions, the bridge of the instrument - the piece of wood that raises the strings above the body—is flat, meaning that the bow could not easily single out one string (with the exception of the highest string on the end away from the plucked strings). This feature makes it easy for the instrument to play several strings at once, sounding either multiple drones or chords, and separates the lira da braccio from those bowed instruments with a curved bridge (e.g. violin) which were intended to be played melodically by allowing the performer to single out one string at a time. In other words, the very 
construction of the five-string fiddle and lira da braccio implies use in accompanying a sung melody, rather than as a melodic instrument. ${ }^{23}$ In fact, as late as the sixteenth century the lira da braccio was sometimes referred to as the viola da braccio or merely "viola," its usual name in fourteenth-century literature.

It is only those instruments with off-board strings that can unequivocally be associated with the cantare all' improvviso tradition, and it is a detail often difficult to tell in some of the early depictions. ${ }^{24}$ The iconography indicates, however, that with or without off-board strings, a large number of the bowed instruments had flat bridges, meaning that the performance capabilities were much the same. And although the representations of the instruments are not always clear, it is usually possible to ascertain when the reference to the cantare all'improvviso tradition is intended because the performer is alone and the "audience" is either seated or standing and listening (see Illustration 2), as opposed to performers in ensembles of two or more musicians, and "audiences" that are engaged in dancing. The seated viola player in Andrea da Bonaiuto's "Allegory of the Dominican Order" in the Spanish Chapel of Santa Maria Novella in Florence, for example, is clearly playing a fivestring fiddle with off-board drone, whereas in Buonamico Buffalmacco's "Triumph of Death" fresco in the Campo Santo in Pisa, the deteriorated state of the fresco does not allow us to determine if the instruments has an off-board string. A similar amount of deterioration blurs the needed details in Giotto's "Wedding Procession of the Virgin" in the Cappella della Scrovegni in Padua. In both cases, however (as in Illustration 2), the context suggests that the reference is undoubtedly the same: accompanied performance of poetry. ${ }^{25}$

Throughout the late Middle Ages the cantare all' improvviso tradition of Italian poet-musicians was extremely popular. ${ }^{26}$ The performer was known as a cantastoria or cantimpanca (referring to the platform on which he stood while performing, see Illustration 2), and although they were present in all communities, Florence was especially rich in talented cantastorie, many of whom appeared regularly in particular venues and performed before a loyal audience. Antonio di Guido, for example, who performed in the piazza in front of the church of San Martino and who had "passato ognuno nell'arte di cantare," according to Florentine historian Luca Landucci, ${ }^{27}$ counted among his loyal followers none other than Lorenzo de' Medici. ${ }^{28}$ The title role in Poliziano's "Fabula d'Orfeo" was performed in Mantua ca.1480 by Baccio Ugolino, who sang his lines while playing the lira da braccio. ${ }^{29}$ From at least as early as 1322 the city of Florence had on its staff a civic herald who sang canti morali all' improvviso daily at the mensa of the Signoria and on all important public occasions, such as ceremonies to honour the visit of foreign dignitaries..$^{3 \circ}$ But professional 
musicians and poets were by no means the only performers of improvised music nor the only performers to play the lira da braccio; it was also the instrument most favoured by educated and cultured amateurs. Il Magnifico, who enthusiastically promoted Italian culture by hiring and patronizing artists, writers, and musicians, also participated in its creation by writing poetry and performing himself on the lira da braccio. ${ }^{31}$ Isabella d'Este also played the instrument ${ }^{32}$ as did Leonardo da Vinci, who taught the noted improvisor Atalante Migliorotti (1466-1536) how to improvise to the lira. ${ }^{33}$ The lira da braccio and its cantare all'improvviso function were often used as the symbol of the Italian musical tradition, as contrasted with the written polyphonic repertory that was identified with the northern or Burgundian tradition. ${ }^{34}$

Because the cantare all' improvviso tradition had a very high profile in Florence, the reference in Lippi's painting would have been immediately understood by the contemporary viewer: the young man is about to improvise an accompaniment while he sings poetry; probably the quoted canzona by Petrarch. He is portrayed as being a versatile musician in as much as he is in the company of several different types of instruments, but there is some question about the presence of two lire da braccio. There is little reason for any one musician to possess two of these instruments; it usually was played by itself, and therefore one would be sufficient for anyone. The presence of two recorders, on the other hand, would not be unusual; musicians often would have a pair of wind instruments made in exactly the same dimensions in order to play duets with a colleague, ${ }^{35}$ or would have several different sizes of wind instruments in order to play music in different ranges: soprano, alto, or tenor. But two lire da braccio is an entirely different matter; the only explanation that comes to mind is that the painting may be intended to indicate a sequence of events: standing in his studio surrounded by his musical instruments, the young man has chosen the lira da braccio, and intends to perform the Petrarch canzona. ${ }^{36}$

We should ask what would have been the status or circumstances of the young man in the painting and the reason for his behaviour. The quoted text is from ' $I$ ' vo pensando," the opening canzona in the second section of Petrarch's Canzioniere, ${ }^{37}$ and the passage from which the text is taken refers to making decisions immediately:

\author{
Mentre che 'l corpo è vivo \\ hai tu 'I freno in bailia de' penser tuoi. \\ Deh stringilo or che pòi, \\ chédubbioso è 'l tardar, come tu sai, \\ e ' 1 cominciar non fia per tempo omai. ${ }^{38}$
}


[While your body is alive/ you have your thoughts in your control:/ grasp them while you may/ since it's dangerous to delay as you know,/ and beginning now is not too soon.]

The implication in the textual quotation is that the young man in the painting was intending to set new life goals and pursue them. ${ }^{39}$ If this is what is intended by the scene and the quotation, it would be difficult to believe that the man would have been a professional musician, as is usually assumed..$^{\circ}$ The presence of the instruments and music would indicate that if he were a professional, he was already well along in his career and not in need of a change; a musician who plays woodwinds and lute and reads music, ${ }^{41}$ and who could accompany himself on a lira da braccio in the cantare all'improvviso tradition, would have been extremely well-situated and very much in demand for domestic music making in the courts of the Florentine nobles. Also, a professional poet-musician such as those mentioned above would more likely have requested a quotation from one of his own poems for his portrait, rather than one borrowed from Petrarch. If, however, this young man was a gifted amateur (of which there were many in Florence) with a completely different career in front of him, the implication could well be that he felt he had to give up spending so much of his time in the amateur pursuit of music, and turn instead to his real career. As stated in the poem and implied by the resolute look on the face of the young man, he has resolved to seize the day and change his life. At the same time he would seem to be having second thoughts since he is in the process of tuning the drone string on his lira da braccio in anticipation of singing all'improvviso.

\section{Singing Angels}

In contrast to Lippi's other musical paintings, it is what is not present in Lippi's tondo, "Madonna and Child with Saint John the Baptist and Angels," (Illustration $3)^{42}$ as well as the musical details in the painting, that hold special interest for music historians. The painting is unusual because the music on the scroll held by the three kneeling angels is a real polyphonic composition, one of the earliest known paintings to contain such a work. ${ }^{43}$ It is more usual for a painter to suggest music simply by placing indistinct marks on the page, as Lippi does, on a book and sheet of paper, in his portrait of the musician. In the "Madonna and Child," however, he has included part of an actual composition that can be read and performed (Illustration 4 and example 1). ${ }^{44}$ All that we can see of the music is the first half of a two-section piece, a rather common format for the period. The viewer is left to imagine the existence of the other half on the remainder of the scroll that faces away from the viewer, and 
to reinforce that image the painter has included five additional notes, barely visible on a small section of the scroll that turns back. The composition is for three voices, written in the simple style typical of sacred forms such as the lauda, as well as several of the secular forms of the period. Although not unusual in stylistic terms, the music is interesting from several other points of view: first, it is clear that although the angels are singing, the music has no text; second, the piece begins by quoting another composition; and last, we might ask why Lippi would go to the trouble of carefully painting the correct notes of a composition which would be seen only upside down, meaning that it would have been nearly impossible for anyone to read.

The absence of words with the music would seem to have been an intentional omission on the part of the painter rather than something caused by lack of space. As Illustration 4 shows, there was ample room on the music scroll for the painter to have identified two of the parts: he clearly marks the "tenor" part beginning halfway along the first staff of music, and the "contra[tenor]" part on the lower staff; this was standard practice for the time. The part at the beginning of the first staff, therefore, is conventionally understood to be that of the highest, or superius part. Even if space limitations would not allow the artist to insert the entire song text, there is sufficient space under the beginning notes of the superius part to identify the text if there was one. Since Lippi had gone to such pains to include the musical notes accurately, it would seem that if there was a text in his exemplar, he would have included it as well.

For music historians this is evidence of an interesting performance practice: that singers often sang without a text. It would seem that during the Renaissance period, even when the music did have a text, Italian singers often preferred to omit it. There is additional evidence that this was true: for example, a large number of song books intended for Italian courts during the fifteenth century are without text, or with incomplete text, even though the pieces they contain are known from other sources to have had full texts. ${ }^{45}$ Lippi's painting, however, is the earliest example to present a clear and unequivocal picture of such a practice-one that otherwise has been so incompletely recorded.

The musical composition included in Lippi's tondo begins (see Music example 1) by borrowing the distinctive rhythm as well as the first several notes of another composition that was very popular in Florence at the time: "Fortuna disperata," a three-part piece written approximately in the years $1476-78$ by the Florentine composer Ser Felice di Giovanni; a work that became one of the most popular compositions of the early Renaissance (see Music example 2). ${ }^{46}$ Lippi's tondo music quotes the first five notes of Ser Felice's "Fortuna" tenor part, and the first four notes 
of its superius, although reversing the position of the parts (see brackets "a" and " $b$ " in Music examples 1 and 2). 47 The technique of borrowing notes from another composition was quite common during the late Middle Ages and Renaissance. Many compositions borrowed not only the opening notes of another piece, but sometime entire melodies or complete sections. ${ }^{48}$ There were several reasons for musical quotation, including the intention to associate the new composition with its model by conjuring up the other piece in the minds of the listeners, similar to the purpose of literary quotation.

On that level the source of the musical quotation for the Lippi tondo seems to be an unusual choice. Since the purpose of the tondo would appear to be devotional, the original text of "Fortuna disperata," concerning hopeless fortune, would at first seem inappropriate for this scene:

\author{
Fortuna disperata \\ Iniqua \& maladecta \\ Che di tal Donna electa \\ La fama ha dinegata \\ Fortuna disperata \\ Iniqua \& maladecta. \\ Sempre sia bestemmiata \\ La tua perfida fede \\ Che in te non ha merzede \\ $\mathrm{Ne}$ fermeza fondata \\ Fortuna disperata \\ Iniqua \& maladecta \\ O morte dispietata \\ Inimica \& crudele \\ Amara piu che fele \\ Di malitia fondata \\ Fortuna disperata \\ Iniqua \& maladecta. ${ }^{49}$ \\ [Hopeless fortune, \\ Unjust and cursed, \\ Who has defamed the reputation \\ Of so distinguished a lady. \\ Hopeless fortune... \\ May your treacherous faith \\ Always be cursed, \\ For there is no mercy in you,
}




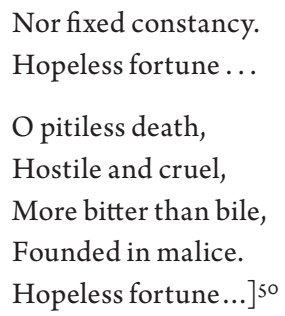

Since the "Fortuna" melody was the most borrowed melody of the period, with over 40 separate compositions based on all or part of it, one might speculate that in this case the choice of musical model would have been based solely on the popularity of the "Fortuna" melody, but not for the purpose of suggesting its text; and that is certainly possible. ${ }^{51}$ There existed at the time the canta si come tradition in which popular melodies were given new texts; a love song would receive devotional text and serve as a devotional lauda, or the reverse, and so it is not always necessary to associate a melody with a single text..$^{2}$ There is, however, another possibility which, although highly speculative, is worth presenting here. It involves the person for whom the "Fortuna disperata" text was probably written: Simonetta Cattaneo, wife of Marco Vespucci, close friend of the Medici, and the probable model for "Flora" in Sandro Botticelli's "Birth of Venus" and "Primavera." 33

Simonetta was so revered by the Medici that after winning the 1475 joust held in celebration of a peace treaty with Venice, Giuliano de' Medici dedicated his victory to her, publically acknowledging her as his mistress. The joust is celebrated in the lengthy and unfinished poem Stanze cominciate per la Giostra del Magnifico Giuliano di'Medici by Angelo Poliziano, which includes direct references to Simonetta. Sadly, the year following the joust (1476), Simonetta died of tuberculosis at the age of 23 . Her death was memorialized in numerous poems, including four sonnets by Lorenzo de'Medici as well as four Latin epitaphs by Poliziano. ${ }^{54}$ Although Poliziano began the Stanze shortly after the joust, he was still writing it at the time of Simonetta's untimely death. Taking the changed circumstances into consideration, he first depicts Simonetta as herself, crowning Giuliano after his victory, and then dying and returning immediately as Fortuna; it is in that guise that she also appears to Giuliano in a dream later in the poem.

With the reference to Simonetta as Fortuna in mind, it is now possible to read the text of "Fortuna disperata" as a reference to her untimely death which denied her the fame she deserved. In that case the word Fortuna can be seen to have both its meaning as "fortune" as well as being an embodiment of Simonetta herself.55 Since her friendship with the Medici was so strong, it is therefore possible to imagine 
either Giuliano or Lorenzo commissioning the original text of "Fortuna disperata" from one of the poets in their circle (the author is unknown), and later requesting a musical setting from Ser Felice di Giovanni, one of the singers at the Duomo. ${ }^{56}$ Given that probability, it would seem to follow that shortly afterward, one of the Medici would have commissioned the young Filippino to further immortalize their grief in a devotional painting that included music referring to Simonetta's death. ${ }^{57}$ Filippino surely would have been well acquainted with his teacher's model, and as a member of the Medici circle he undoubtedly would have been familiar with both the text of "Fortuna" and Ser Felice's new composition. The terms of the commission, therefore, would have been to depict the Christ child, his mother, and the city of Florence (symbolized by the patron saint of Florence, St. John the Baptist), joining with the angels in mourning the death of the person identified by Poliziano as the personification of Fortuna. ${ }^{5} \mathrm{~A}$ fitting memorial to a well-loved young lady who was, in Lorenzo's words:

una donna, la quale mosse a compassione generalmente tutto il popolo fiorentino. Non è gran maraviglia, perché di bellezze e gentilezze umane era veramente ornata quanto alcuna che inanzi a.llei fussi suta; e, infra l'altre sue excellenti dote, aveva così dolce e attrattiva maniera, che tutti quelli che con lei avevono qualche domestica notizia credevono da essa sommamente essere amati... oltre alla compassione nacque accirazione che lei nella morte avesse superato quella bellezza che, viva, pareva insuperabile; in quelli che prima non la conoscevano, nasceva uno dolore e quasi rimordimento di non avere conosciuto sì bella cosa prima che ne fussino al tutto privati, e allora conosciutola per averne perpetuo dolore. 59

[A woman who inspired compassion in all of the people of Florence. This was no great miracle because she was truly adorned with as much beauty and human gentility as anyone could imagine. And in addition to all her excellent attributes, she had such a sweet and attractive manner, that everyone who had daily contact with her believed to be fully loved by her.... Further, the inborn compassion of such a beautiful person who, when alive had appeared unsurpassable, has been overcome by death. Even in those who previously did not know her, was born a sadness and remorse to not have known so beautiful a thing before everyone had been deprived of her; and therefore to have known her is to have perpetual sadness.]

In this case the reference in the painting to Fortuna - both the music and the textwould have been entirely appropriate. 


\section{Filippino as Musician}

Although Emanuel Winternitz concluded that so many fanciful, unplayable musical instruments in Filippino's paintings indicated that he "could not have been a practising musician,"60 there is good reason to believe that he was indeed an amateur musician. In addition to careful accuracy in the details of music scenes in his paintings that suggests an intimate understanding of musical performance, there is factual evidence that he performed on at least two different types of instruments and owned a book of secular music. At the time of his death in 1504, the inventory of his workshop contained the following: "a large lute in its case; and five good zufoli [recorders] in a small bag, and a chansonnier." ${ }^{\text {61 }}$ It cannot escape the reader's notice that these instruments are present in the painting of "The Musician," suggesting that the instruments in that painting could well have been the personal possessions of the artist.

The presence of a lute in Filippino's studio is especially tantalizing for further conjecture since at the time it was one of the most versatile instruments, capable of playing melodies and/or providing accompaniment. It was therefore useful as a solo instrument, in conjunction with singers, or with other instruments. Lute players were usually capable of reading music — a fact affirmed for Filippino by the presence of the chansonnier in his inventory-and it is known that their training in the last half of the fifteenth century included instruction in the basic theory of music, which also included composition. When linked with the other musical information implied in the two paintings, the presence of both a lute and some woodwind instruments among his possessions suggests that Filippino probably was a fairly capable amateur musician who actively participated in the company of the many versatile, cultured people who gathered in Florence at the courts of the noble families, including that of the Medici, where music making by professionals as well as amateurs was a regular occurrence. Based on what is known about the cultural life in Florence and the place of music in that society, I would like to end this essay with some additional speculations as to possible further implications of the association between some of the images discussed above and Filippino's musical involvement.

First of all, the musical composition in the tondo, while being competent, is not especially advanced. It does not compare to the more refined and polished works of the finest professional composers who worked in Florence at the time, as for example, Heinrich Isaac, ${ }^{62}$ nor is the composition quite the equal of its "Fortuna Disperata" model by the lesser composer Ser Felice. At the same time, however, it would be a 
respectable product for an amateur. If, as I have speculated, Filippino's interest in lute playing indicates that he probably had learned composition, it is not improbable that he is the composer of the music in the tondo. The level of composition would have been well within the capabilities of a gifted amateur. And since the "Fortuna" quotation suggests the motive for the commission, the inclusion of an original composition by the painter would have been a marvellous personal tribute to Simonetta. And although the music is accurately represented, it is upside down and thus not easy to decipher. It therefore would have provided a symbolic reference that only a few would know, shared perhaps only by the patron and the artist, or possibly an entirely secret conceit on the part of the artist alone.

To move further along in this direction of unsupportable but possible conjecture, we might look again at the subject of "The Musician." As noted above, some of the instruments in the painting are the same as those found later in Lippi's possession at the end of his life. Given the attitude towards traditional Italian music at the Medici court - coupled with the known fact that Lorenzo himself, as well as a number of the cultured amateurs who frequented his court, played the lira da braccio-could the "musician" actually be the artist himself? The face is not unlike the self-image of Filippino in his earlier "Crucifixion of Saint Peter" in the Brancacci chapel ${ }^{63}$ and with the probable date of the painting $1483-85$, the age of the "musician" appears to be similar to that of Filippino at that time: between 25 and 27. In that case, the quoted Petrarch text could have something to do with Filippino's move to Rome and the change of artistic style that followed soon after the painting of this portrait. This, of course, would make Filippino one of the earliest known artist to memorialize himself in a solo self-portrait, and we might be suspicious that an artist would depict himself as a musician, his avocation, rather than with the symbols of his profession. ${ }^{64}$

These final thoughts are merely musings at best, perhaps more along the line of the fantastic images that Filippino included in some of his works, than on a par with his realistic depictions of functional instruments. But the information contained both directly and symbolically in the musical images within the paintings, coupled with the revelation about the artist's probable activity as an amateur musician, does suggest new avenues for exploration. This, however, exceeds the limits of my expertise, and I leave it to art historians who are better qualified to consider the likelihood of such conjectures.

Speculations aside, there is no question that Fillipino Lippi's avocation as an amateur musician resulted in invaluably accurate as well as beautifully executed records of music instruments and musical practices. The field of music history is considerably richer for them. ${ }^{65}$ 


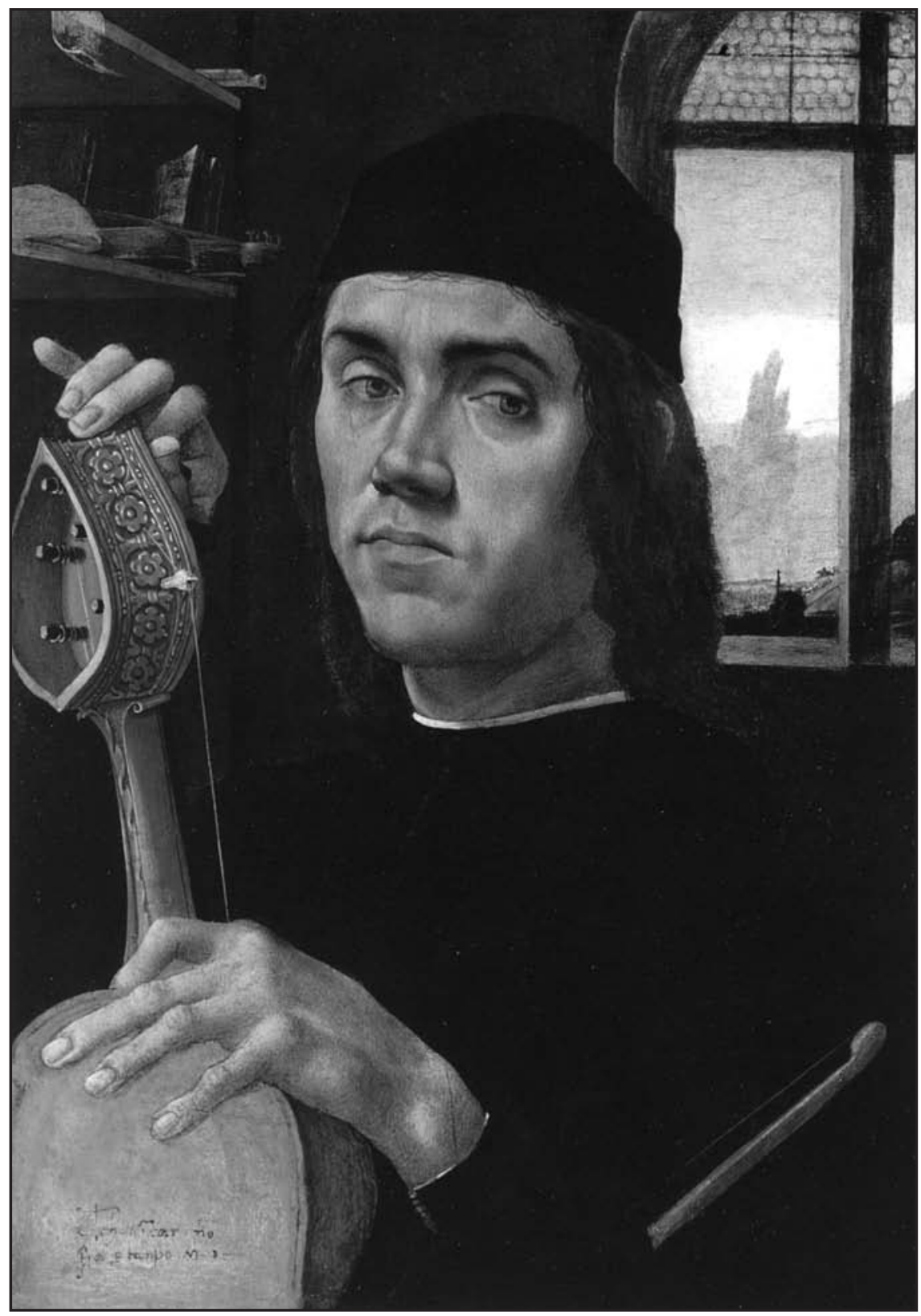

\section{Illustration 1}

Filippino Lippi. "Portrait of a Musician." National Gallery of Ireland 


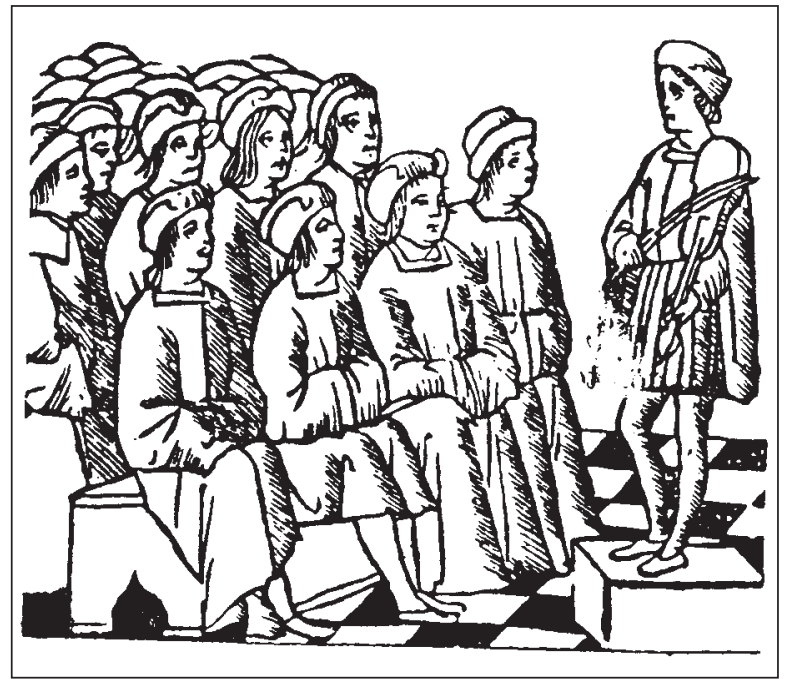

Illustration 2

A fifteenth-century cantimpanca, with his lira da braccio.

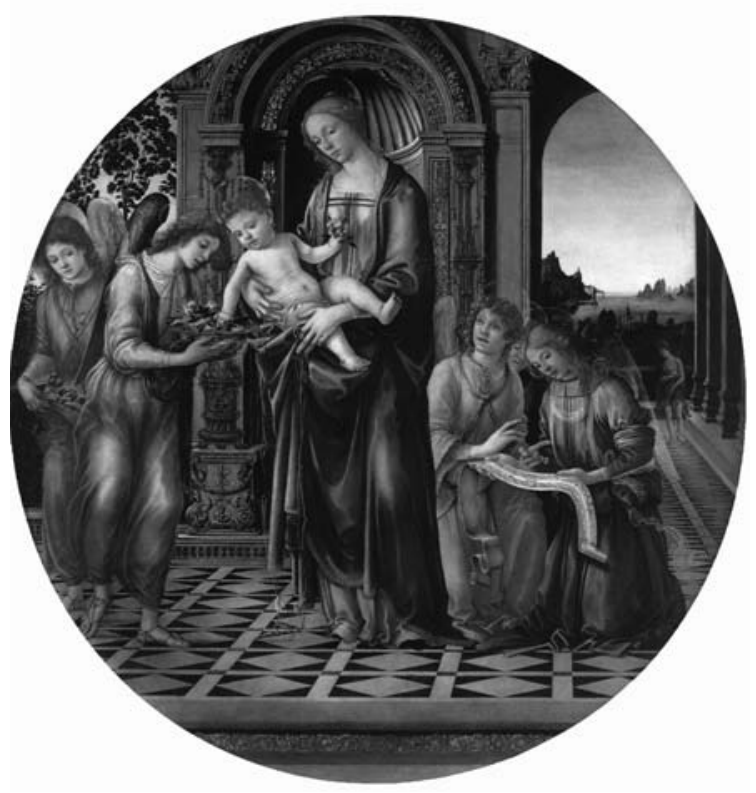

Illustration 3

Filippino Lippi. "Madonna and Child with Angels." Ente Cassa di Risparmio di Firenze 


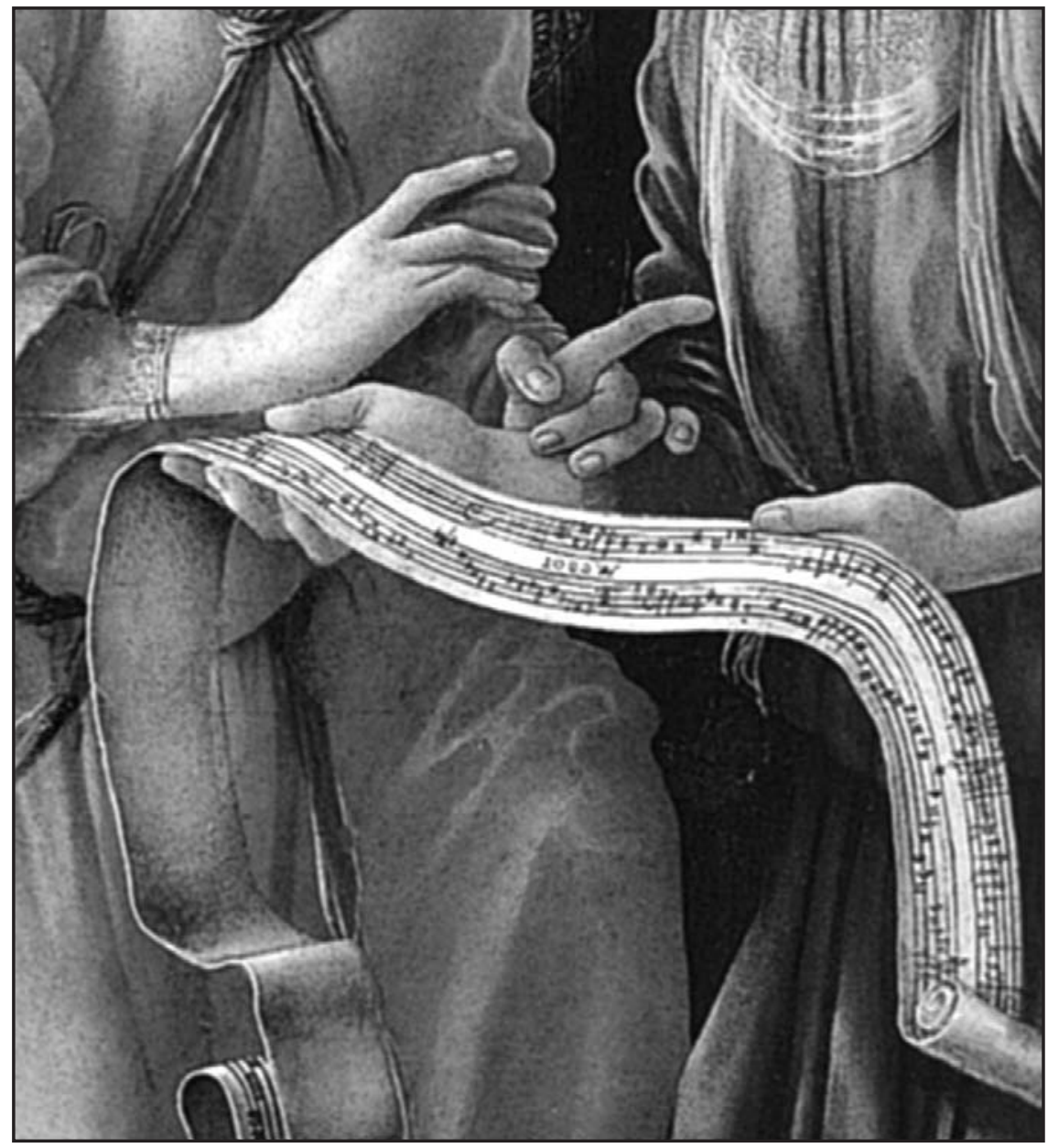

Illustration 4

Filippino Lippi. "Madonna and Child with Angels." detail 

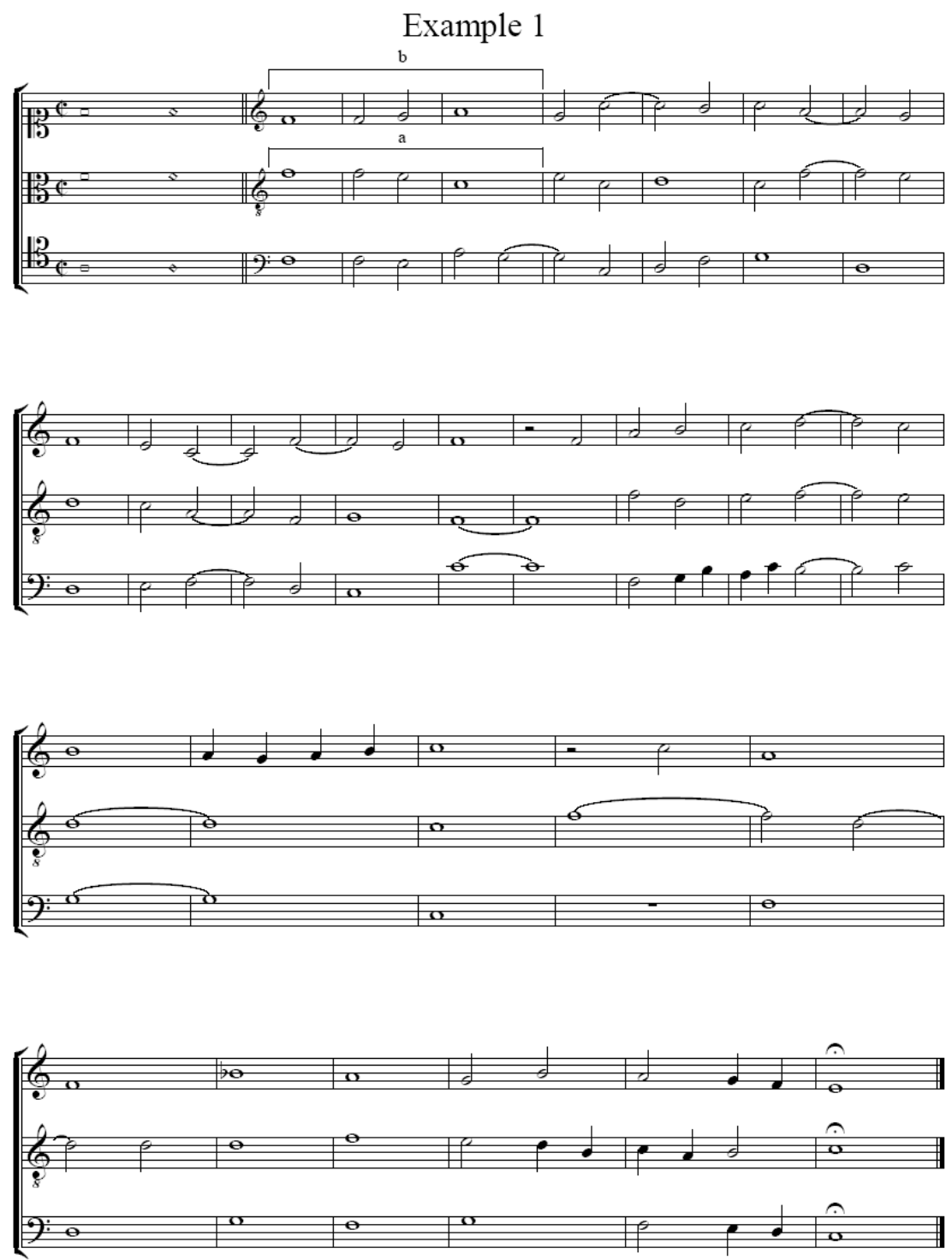

Music Example 1

Music in "Madonna and Child with Angels." 


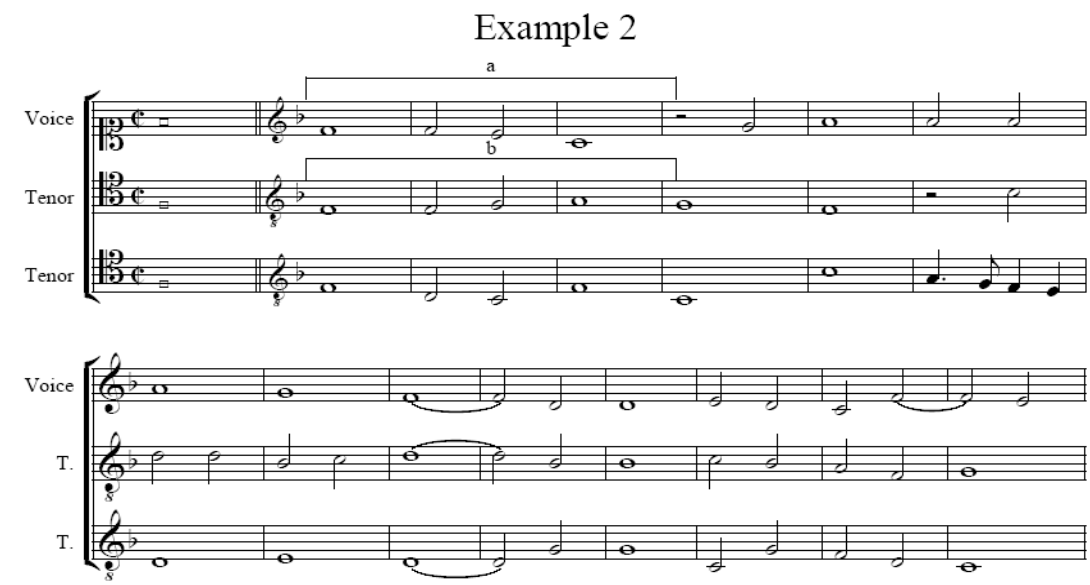

Music Example 2

Ser Felice di Giovanni. "Fortuna disperata", opening section.

\section{NOTES}

1. Studies of music and instruments that take advantage of iconographic representations include Volker Scherliess, Musikalische Noten auf Kunstwerken der italienischen Renaissance bis zum Anfang des 17. Jahrhunderts (Hamburg: Hamburger Beiträge zur Musikwissenschaft 8, 1972); Emanuel Winternitz, Musical Instruments and their Symbolism in Western Art. Studies in Iconology (New Haven: Yale University Press, 1960. $2^{\text {nd }}$ ed 1979); Colin Slim, Painting Music in the Sixteenth Century, Variorum Collected Studies Series (Aldershot: Ashgate, 2002); Marcus Dekiert, Musikanten in der Malerei der niederländischen Caravaggio-Nachfolge: Vorstufen, Ikonographie und Bedeutungsgehalt der Musikszene in der niederländischen Bildkunst des 16. und 17. Jahrhunderts (Munster: Lit, 2003); Sylvia Ferino-Pagden, ed., Dipingere la musica: Strumenti in posa nell' arte del cinque e seicento (Milan: Skira, 200o); Annalisa Bini, Claudio Strinati, and Rosella Vodret, ed., Colori della Musica: Dipinti, strumenti e concerti tra Cinquecento e Seicento (Milan: Skira, 200o); and all issues of the annual Imago Musicae.

2. See Timothy J. McGee, "Misleading Iconography: The Case of the 'Adimari Wedding Cassone," Imago Musicae IX-XII (1992-95), pp. 139-57; and Leslie Korrick, "Instrumental Music in the Early $16^{\text {th }}$-century Mass: New Evidence," Early Music 18 (1990), pp. 359-70, especially pp. 364-68.

3. See Winternitz, Musical Instruments, Chapter 2.

4. For a recent study of Filippino Lippi see Patrizia Zambrano and Jonathan Katz Nelson, Filippino Lippi (Milan: Electa, 2004). On Florentine style in general see Patricia 
Lee Rubin and Alison Wright, Renaissance Florence: The Art of the 1470 (London: National Gallery of London, 2000). The discussion of Filippino's work is on pp. 109-110.

5. Winternitz noted his importance in two articles directed at Lippi's paintings: "Muses and Music in a Burial Chapel: An Interpretation of Filippino Lippi’s Window Wall in the Cappella Strozzi," and "Musical Instruments for the Stage in Paintings by Filippino Lippi, Piero di Cosimo, and Lorenzo Costa," reprinted as Chapters 13 and 16 in his Musical Instruments.

6. By the end of the fifteenth century nakers and tambourines had been in use for centuries and are still in use. The "S" trumpet, however, was a development of the late fourteenth century: see Keith Polk, German Instrumental Music of the Late Middle Ages (Cambridge: Cambridge University Press, 1992), pp. 46-48; Patrick Tröster, Das Alta-Ensemble und seine Instrumente von der Spätgotik bis zur Hochrenaissance (1300-1550), Eine musikikonografische Studie (Tübingen: MVK, 2001), p. 185. A late fifteenth-century sculpture by Benedetto da Maiano presently in the entrance hall of Florence, Museo Nazionale del Bargello depicts the Florentine trumpet ensemble performing on instruments in this shape. See discussion of the sculpture in Doris Carl, Benedetto da Maiano, ein florentiner Bildhauer an der Schwelle zur Hochrenaissance, 2 Vols. (Regensburg: Schnell \& Steiner, 2006), vol. 1, pp. 423-41, and vol. 2, Plates 201-06.

7. Winternitz discusses the instruments and their possible symbolism in Musical Instruments, pp. 211-25.

8. On the Carafa Chapel painting see Gail Geiger, Filippino Lippi's Carafa Chapel (Kirksville: Sixteenth Century Journal Publishers, 1986). The problem of the origin of the earliest trombone is discussed in McGee, "Misleading Iconography."

9. Emanuel Winternitz, "Muses and Music in a Burial Chapel: An Interpretation of Filippino Lippi’s Window Wall in the Strozzi Chapel”, in Mitteilungen des Kunsthistorischen Institutes in Florenz XI (1963-1965), p. 270.

10. It should be noted that there is not complete agreement among specialists as to the attribution of this work. It has been credited to Raffaellino del Garbo among others, but see the discussion in Zambrano and Nelson, pp. 262, 342-4; and in Pierluigi De Vecchi, Daniel Arasse, and Jonathan Katz Nelson, ed., Botticelli and Filippino: Passion and Grace in Fifteenth-Century Florentine Painting (Milan: Skira, 2004), p. 230.

11. Patrizia Zambrano, in Zambrano and Nelson, p. 343, discusses the folio as containing music which is no longer legible.

12. The first printer of music was Ottaviano Petrucci in Venice, who in 1501 printed Odhecaton, a collection of 96 (not 100) pieces of polyphonic music.

13. Musicial ensembles and their repertories are discussed in Keith Polk, "Ensemble Performance in Dufay's Time," Dufay Quincentenary Conference, ed. Allan W. Atlas (Brooklyn: Brooklyn College, 1976), pp. 61-75.

14. On the various names and shapes of the lira da braccio see Emanuel Winternitz, "Lira da Braccio," in Die Musik in Geschichte und Gegenwart, vol. 8 (Kassel: Bärenreiter, 1960), col. 935-54, condensed in Winternitz, Musical Instruments, Chapter 5. 
15. On the subject of the possible performance of composed polyphony on the lira da braccio during the late fifteenth century see two essays by William F. Prizer: "Isabella d'Este and Lorenzo da Pavia, 'master instrument maker', Early Music History 2 (1982), pp. 87-127, and "The Frottola and the Unwritten Tradition," Studi musicali Xv (1986), pp. 8-9.

16. We can see in the painting that the instrument on the shelf has the older shape with flat top and bottom. Presumably, that is also the shape of the instrument in the musician's hands.

17. See Werner Bachmann, The Origins of Bowing, trans. Norma Deane (London: Oxford University Press, 1969), plates 69-76. Additional representations can be found in Mary Remnant, “The Diversity of Medieval Fiddles," Early Music 3 (1975), pp. 47-49; and Howard Mayer Brown, "The Trecento Fiddle and its Bridges," Early Music 17 (1989), pp. 311-29. Winternitz, "Lira da Braccio," and Musical Instruments, Chapter 5, and Sterling Jones, The Lira da braccio (Bloomington: Indiana University Press, 1995), only consider the instrument from the time it was usually referred to as the lira da braccio, although it is clear that the basic construction and performance attributes, including both the way in which it was played and the repertory associated with it, date from much earlier. Both Winternitz and Jones, however, show depictions of the earlier, five-string instrument.

18. See the discussion of this symbolism in Winternitz, Musical Instruments. p. 89. On the representation of Orfeo in Italian art see Giuseppe Scavizzi, "The Myth of Orpheus in Italian Renaissance Art, 1400-1600," in Orpheus; The Metamorphoses of a Myth, ed. John Warden (Toronto: University of Toronto Press, 1982), pp. 111-62.

19. Jones, chapters 3 and 4 , presents tables of the variety of shapes and number of strings found in representations through the later centuries of its popularity. Also see discussion and illustrations in Winternitz, "Lira da Braccio," and Musical Instruments, ch. 5 .

20. Scavizzi includes illustrations of Orfeo with lute, lira da braccio, and a seven-string lyre.

21. An early representation of a performer plucking the off-board strings is in a fourteenth-century copy of a Boethius manuscript, Naples Biblioteca Nazionale, Cod. V. A. 14 , Plate 76 in Bachmann.

22. Most depictions, understandably, show the front of the instrument. This is the earliest known representation showing details of the recessed peg box and the way in which the drone string is directed into the peg box.

23. The issue of construction and repertory for the early fiddle is somewhat complicated. See discussion in Brown, "The Trecento Fiddle."

24. For representations of early bowed instruments see Howard Mayer Brown, "Catalogus. A Corpus of Trecento Pictures with Musical Subject Matter," Imago Musicae 1 (1984), pp. 189-243; 2 (1985), 179-281; 3 (1986), 103-87; 5 (1988), 167-241. 
25. For additional discussion of the instrument and its function see Timothy J. McGee, Civic Musicians and the Ceremonies of Republican Florence, 1282-1532, Chapter 3, forthcoming.

26. The tradition and its literature are discussed in Francesco Flamini, La lirica toscana del Rinascimento anteriore ai tempi del Magnifico (Pisa, 1891; repr. Florence, 1977); Ezio Levi, "I cantari leggendari," Giornale Storico della Letteratura Italiana suppl. 16 (1914); James Haar, "Improvvisatori and their Relationship to $16^{\text {th }}$ century Music," in his Essays on Italian Poetry and Music 1350-160o (Berkeley: University of California Press, 1986), pp. 76-99; Nino Pirrotta, Music and Culture in Italy from the Middle Ages to the Baroque (Cambridge: Harvard University Press, 1984), pp. 26-112, 145-58, and in his chapter "Orpheus, singer of strambotti," in Nino Pirrotta and Elena Povoledo, Music and Theatre from Poliziano to Monteverdi (Cambridge: Cambridge University Press, 1982); William F. Prizer, "The Frottola and the Unwritten Tradition," pp. 3-37; and Timothy J. McGee, "Cantare all' improvviso: Improvising to Poetry in Late Medieval Italy," Improvisation in The Arts of the Middle Ages and Renaissance, Early Drama, Art and Music Monograph Series 30 (Kalamazoo: Medieval Institute Publications, 2003), pp. 31-70.

27. Luca Landucci, Diario Fiorentino, ed. Iodoco Del Badia (Firenze: Sansoni, 1883), p. 51.

28. On Antonio di Guido, see Becherini, "Un canta in panca Fiorentino, Antonio di Guido," Rivista musicale italiana 50 (1948), pp. 241-47.

29. The date of the performance of Poliziano's work is not secure. See the discussion in Pirrotta and Povoledo, Music and Theatre, p. 6, where a date in the 1480 s is proposed. A more recent discussion in Antonia Tissoni Benvenuti, L'Orfeo del Poliziano, con il testo critico dell'originale e delle successive forme teatrali (Padova: Antenore, 1986), pp. 89-103, proposes its performance a decade earlier. See also Paola Ventrone, “'Philosophia. Involucra Fabularum': La Fabula di Orpheo di Angelo Poliziano," Comunicazioni Sociale 19 (1997), pp. 137-80.

30. For discussion see Timothy J. McGee, "Dinner Music for the Florentine Signoria 1350-1450," Speculum 74 (1999), pp. 95-114.

31. The evidence that Lorenzo played the lira da braccio is presented in FrankA. D'Accone, "Lorenzo il Magnifico e la musica," in La Musica a Firenze al tempo di Lorenzo il Magnifico, ed. Piero Gargiulo (Florence: Olschki, 1993), p. 234.

32. William F. Prizer, "Isabella d'Este and Lorenzo da Pavia," p.107.

33. As pointed out in Colin Slim, "The Lutenist's Hand," in Painting Music in the Sixteenth Century, Variorum Collected Studies Series (Aldershot: Ashgate, 2002), pp.32-4 (originally published in the Journal of Leonardo Studies and Bibliography of Vinciana I, 1988). See also Emanuel Winternitz, Leonardo da Vinci as a Musician (New Haven: Yale University Press, 1982), pp. xxii-xxiv.

34. This relationship is discussed in Robert Nosow, "The Debate over Song in the Accademia Fiorentina," Early Music History 21 (2002), pp. 175-221. 
35. During the fifteenth century there was no standardization of sizes for wind instruments, meaning that any two instruments would not necessarily play at the same pitch unless the instrument maker intentionally constructed them to do so.

36. Although sequential events in a painting is usually associated with medieval art, there are a number of Renaissance examples, including Masaccio's "Tribute Money," which is located directly above Filippino's "The Raising of the Son of the Prefect of Antioch," in the Brancacci Chapel at Santa Maria del Carmine. On the subject of sequential painting in general see Marilyn Lavin, The Place of Narrative: Mural Decoration in Italian Churches, 431-1600 (Chicago: University of Chicago Press, 1990), and her discussion of the Brancacci paintings on pp.131-38.

37. The source of the quotation was first identified by Jonathan Katz Nelson in Botticelli and Filippino, p. 230.

38. Francesco Petrarca, Canzoniere, Trionfi, Rime Varie e una Scelta di Versi Latini, ed. Carlo Muscetta and Daniele Ponchiroli (Torino: Giulio Einaudi editore, 1958), p. 331, lines $27-36$.

39. This is the conclusion of Nelson in Botticelli and Filippino, p. 230.

40. See the discussion by Nelson, Idem.

41. As stated earlier, it is not clear that the book and paper in the painting are actually music books, but the presence of the lute is strong evidence that the performer read music; reading and composing music were traditional in the training of a lutenist, see below.

42. The painting is also referred to as the Corsini Tondo. See discussion in Zambrano and Nelson, Filippino Lippi, pp. 341-42.

43. There are numerous earlier paintings with short chant quotations such as "Gloria in excelsis Deo," but this may be the earliest painting to hold a piece of secular polyphonic music.

44. My transcription of the music appeared originally in Timothy J. McGee, "Singing Without Text," Performance Practice Review 5 (1993), pp. 1-31. An earlier transcription can be found in Scherliess, pp. 4-5.

45. For additional discussion and evidence see McGee, "Singing Without Text."

46. On Ser Felice see Frank A. D'Accone, "Some Neglected Composers in the Florentine Chapels, ca. 1475-1525," Viator 1 (1970), pp. 263-88. On the identification of Ser Felice as composer and what he may have composed see Joshua Rifkin, "Busnoys and Italy: The Evidence of Two Songs," pp. 563-71, and Honey Meconi, "Poliziano, Primavera, and Perugia 431: New Light on Fortuna desperata," pp. 493-97, both published in Paula Higgins, ed., Antoine Busnoys: Method, Meaning, and Context in Late Medieval Music (Oxford: Oxford University Press, 1999). Credit for recognizing the musical quotation from "Fortuna" goes to Bonnie Blackburn, reported in Botticelli and Filippino, p.166.

47. The Ser Felice "Fortuna disperata" music is from Paris, Biblioteque Nationale, Ms 4379, fol. 40v-41r, based on the transcription in Meconi, "Poliziano, Primavera," pp. 471-2. 
48. See Howard Mayer Brown, "Emulation, Competition, and Homage: Imitation and Theories of Imitation in the Renaissance, "Journal of the American Musicological Society 35 (1982), pp. 1-48.

49. This version of the text is that found in ms. London, British Library, 16459. In later versions of the text "dinegata" (line 4 ) has been changed to "dinegrata," significantly changing the meaning of the poem. According to Meconi, "Poliziano, Primavera," pp. 467-71, the London text was probably the original version.

50. Text and translation from Meconi, "Poliziano, Primavera," p. 467.

51. For a transcription of 36 composition based on Ser Felice's original composition see Honey Meconi, ed., Fortuna Desperata; Thirty-Six Settings of an Italian Song, Recent Researches in the Music of the Middle Ages and Early Renaissance, Vol. 37 (Middleton: A-R Editions, 2001).

52. On this tradition see Giulio Cattin, "I 'cantasi come' in una stampa di laude della Biblioteca riccardiana (Ed. r. 196)," Quadrivium 19 (1978), pp. 5-52.

53. On the identification of 'Flora,' see Charles Dempsey, "Portraits and Masks in the Art of Lorenzo de' Medici, Botticelli, and Politian's Stanze per la Giostra,” Renaissance Quarterly 52 (1999), pp. 17-21. The identification of the "Fortuna disperata" text with Simonetta Cattaneo is discussed in Meconi, "Poliziano, Primavera," pp. 481-2. On the relationship between Botticelli and the Medici see Antonio Paolucci, "Botticelli and the Medici: A Privileged Relationship," in Botticelli and Filippino, pp. 69-76.

54. On the sonnets and epitaphs see the discussion in Meconi, "Poliziano, Primavera," pp. 480-84. Lorenzo's sonnets are included as the first four in his Comento de' miei sonetti, ed., Tiziano Zanato (Florence: Olschki, 1991), pp. 155-68. Dempsey also discusses the sonnets in "Portraits and Masks," pp. 26-7.

55. This point is expanded by Meconi in "Poliziano, Primavera," pp. 481-84.

56. The Medici freely and frequently borrowed singers, instrumentalists, and composers for their own use, having secured their employment in the services of the civic government and at the various churches. See D’Accone, "Lorenzo il Magnifico e la musica."

57. To follow along this line of speculation, since Giuliano was murdered in 1478, it could have been Lorenzo who commissioned the painting. Another possibility is that the original commission came from Giuliano who did not live to see its completion which is usually dated as 1482 .

58. We might also speculate that an additional symbol is that the Christ Child is handing his mother flowers $=$ flora.

59. Lorenzo de' Medici, Comento, Argomento I \#17, pp. 155-57.

6o. Winternitz, "Muses," p. 274.

61. 1504, 24 aprile. Inventario della casa e della bottega di Filippino, Firenze, Archivio di Stato, Notarile antecosimiano, 563 (ser Giovanni di ser Piero del Serra, 1497/1504)

(220) uno liuto gramde cholla chassa

(221) 5 zufoli buoni in una sacchetto

(224) uno chamzioniere 
Reproduced in Doris Carl, "Das Inventar der Werkstatt von Filippino Lippi aus dem Jahre 1504", Mitteilungen des Kunsthistorischen Institutes in Florenz 31 (1987), pp. 373-91: documento II, pp. 384-89; and Zambrano and Nelson, pp. 626-27.

62. Isaac is responsible for several settings using either the superius or tenor part of "Fortuna disperata," see Meconi, Fortuna Desperata, settings 10, 11, 15, and 16. Isaac first arrived in Florence in the Fall of 1484. See Frank A. D’Accone, "Heinrich Isaac in Florence: New and Unpublished Documents,” The Musical Quarterly 49 (1963), pp. $464-83$.

63. The painting and the image of Filippino are presented and discussed by Jonathan Katz Nelson in Botticelli and Filippino, p. 86. See also another possible portrait of Filippino from much earlier in Fra Filippo Lippi's "Dormition, Assumption, and Coronation of the Virgin," from 1469, in the Duomo in Spoleto. Discussion and reproduction in Joanna Woods-Marsden, Renaissance Self-Portraiture: The Visual Construction of Identity and the Social Status of the Artist (New Haven: Yale University Press, 1998), pp. 59-6o, plates 43,44 .

64. On early self-portraits see Woods-Marsden; also, Katherine McIver, "Maniera, Music, and Vasari," Sixteenth Century Journal 28 (1997), pp. 45-55.

65. I am grateful to art historians Leslie Korrick and Jonathan Katz Nelson for assistance with this essay. 